\title{
Cardiolipin IgM Antibody Measurement
}

National Cancer Institute

\section{Source}

National Cancer Institute. Cardiolipin IgM Antibody Measurement. NCI Thesaurus. Code C103363.

The determination of the amount of the cardiolipin IgM antibodies in a sample. 